\title{
TEACHING MODULES: LEVELS OF CROSS-SUBSIDY AT A SOUTH AFRICAN UNIVERSITY
}

\author{
C. Serfontein* \\ School of Accountancy \\ https://orcid.org/0000-0002-9079-2552
}

\author{
A. v. A. Smit ${ }^{*}$ \\ Department of Business Management \\ https://orcid.org/0000-0003-0777-0393
}

*University of the Free State

Bloemfontein, South Africa

\section{ABSTRACT}

Traditional universities, typically presenting face-to-face education on-campus, are facing their biggest survival crisis in decades. COVID-19 fast-tracked the impact of the Fourth Industrial Revolution (4IR) on universities in terms of online education, rethinking their core disciplines and even their role in society. In a matter of months, most universities had to embrace technology to educate their students. Huge amounts of money had to be spent to retrain staff and invest in technology, leading to significant increases in spending. In addition, the world is experiencing a massive rise in unemployment, which is already leading to declining student numbers and a need for more affordable education. The primary research objective of this article was to determine the levels of cross-subsidy of teaching modules at a South African university using cost and management accounting principles. The sample consisted of 3689 modules with 286831 students enrolled during 2018 at a selected South African university. The authors of this article are convinced that the costing methodology applied in this study is unique and sound, and, in spite of the fact that the results reflect the figures of only one university, it is quite likely that most traditional universities are facing the same dilemma. The results of this study indicated that 49,7 per cent (1769) of the teaching modules at the related university did not cover their direct cost in 2018. In addition, the 1769 modules not covering their direct costs, accounted for only 5,2 per cent of all enrolments. Hence, if the selected university had to close 47,9 per cent of the modules not covering their direct costs, it would only impact 14867 of 286832 enrolments, which is negligible. The unique contribution of this research is to assist traditional universities to avail resources to fund the critical changes needed to combat COVID-19 and embrace the 4IR.

Keywords: traditional universities, funding, cost accounting, Fourth Industrial Revolution, COVID19 , human resources, financial resources, direct costs, subsidies, tuition fees 


\section{BACKGROUND AND PROBLEM STATEMENT}

Disruptive technology will increase as we enter the Fourth Industrial Revolution (4IR). The advances in automation, as characterised by the 4IR, will have an impact on the nature of the work we perform (Omarjee 2018, par. 3). The 4IR is essentially different from the previous three industrial revolutions that respectively liberated humanity from the use of animal power; enabled mass production; and digitalised humanity (Schwab n.d., par. 3). The 4IR will impact all aspects of work as well as day-to-day environments of the human race (World Economic Forum (WEF) 2016, v; Adendorff, Lutshaba, and Shelver 2018, 8; Yang et al. 2018, 4; Prifti $2019,1)$. The disruption of the 4IR affects business models, employability and, as a consequence, business education (World Economic Forum (WEF) 2016, 8; Prifti 2019, 1). According to Omarjee (2018, par. 3), the evolution of the utilisation of machines in the workplace could displace 75 million jobs between 2018 and 2022. In many countries and industries, the specialities and occupations that are most in demand did not exist a decade ago (World Economic Forum (WEF) 2016, 3).

The impact of the 4IR on higher education has been widely debated. The training and education systems required for the previous industrial revolutions often took decades to develop. However, the current pace of change in education is such that 50 per cent of the knowledge acquired by first year students enrolled in a four year technical degree will be outdated by the time the students graduate (World Economic Forum (WEF) 2016, 20). In order to remain relevant and economically viable, a complete rethinking of the education system is thus required. COVID-19 contributed to the conundrum universities are currently facing. How do traditional universities obtain the required financial resources to implement the radical changes needed to stay relevant and to be sustainable?

COVID-19 resulted in 13 universities in the United Kingdom being on the brink of insolvency and it is expected that the losses incurred by the higher education sector will amount to between $£ 3$ billion and $£ 19$ billion (Adams 2020, par. 1-2). Many reports indicate that universities in both the USA and Australia are also in serious financial trouble. Even prior to COVID-19, Harvard Business School Professor Clayton Christensen predicted that 50 per cent of the over 4000 colleges and universities in the United States are bound for bankruptcy in the next few decades (Hess 2018, par. 1; Editorial 2020, par. 4). Emanating from the 4IR and accelerated by COVID-19, many experts question the relevance regarding what is being taught and how it is taught at universities, justifying Christensen's prediction. The sudden change to online education and open source learning is also here to stay, destroying the competitive advantage of traditional on-campus universities.

One of the key challenges of the 4IR is to ensure that employees are qualified with the 
competencies required for their specific occupations (Prifti 2019, 1-2). The impact of the next few decades on the planet, individuals and nations will largely be determined by education (Schleicher 2018,9). Universities' active intervention is critical; however, past evidence reveals that they are often too slow to embrace the required change (Hattingh 2016, 1-3; Menon and Castrillon 2019, par. 3). Graduates are faced with various challenges upon entering the labour market due to specific skills demanded by the job market being absent from the education system. Thus, there exists a lack of congruency between the requirements of a job market that is changing as opposed to graduates delivered by the current education system (Ubell 2010; Mesquita, Peres, and Xing 2015). This implies that students and instructors will need to be equipped with new skills, information and tools (Ehlers 2020, 1-9).

The threat to traditional universities must include Massive Open Online Courses (MOOCs) that hold the advantages of education provided at a time and place that suit students (Editorial 2014, 1). Universities reacting too late (or slow) to the technological revolution might have to make dramatic changes to their business model to prevent a decline in their enrolled students client base (Davies 2012, 65). Student numbers are already declining as online education links up with employers and students start preferring online education over traditional universities (Davies 2012, 66; Ostashewski, Howell, and Dron 2017, 184; Shah 2018, par. 1). In future, students could study online at the best universities and with the most relevant experts in the world.

It is clear that "it cannot be business as usual at the university" (Menon and Castrillon 2019, par. 8). Universities are facing major transformation that will require financial as well as human capacity. Research on the 4IR and the rise in online education have emphasised what universities are required to do to address the predicted disruption, but have failed to explain how they will be able to achieve it. Pandemics have a history of forcing the human race to reimagine the world and let go of the past (Roy 2020, par. 47). The statement, falsely attributed to Charles Darwin, seems more true than ever that in a disruptive environment, those who adapt the fastest will survive (Jackson 2015, 4). COVID-19, combined with the 4IR, created a perfect storm, changing the world as we knew it forever. This is not a short-term problem caused by the virus, but simply fast-tracking the inevitable 4IR. Not only did online teaching and opensource learning change the landscape of tertiary education, but what students are being taught and also how students are taught add to the conundrum universities are facing. One of the biggest challenges all organisations is currently confronted with is that management expects more and more from employees without assessing the relevance of existing activities. From both a human and financial perspective, any strategy must include what must be done as well as what not to do anymore. Universities are no exception. 
The research question in this article thus focuses on how traditional universities can free up human and financial resources to ensure that they remain relevant in light of all the challenges faced by the higher education sector, both globally and locally. Where the services delivered are in the public domain, the phenomenon of cross-subsidy is much more prevalent. This is however tolerated to a larger extent since universities have an objective to provide societal benefits. Accurately quantifying the current levels of cross-subsidising provides certain difficulties and combined with the traditional objective of universities of the benefit to society outweighing the importance of financial viability, very little focus has been given to the extent of cross-subsidies at these institutions (Lewis and Pendlebury 2002, 25). Given that traditional universities typically are not-for-profit institutions rendering a diverse range of services (such as presenting modules), we could not find any similar research attempting to calculate the levels of cross-subsidy of modules at universities internationally.

\section{RESEARCH OBJECTIVES}

The primary objective of this article is to determine the levels of cross-subsidising of teaching modules at a South African university using cost and management accounting principles. Given the challenges of retraining academic staff to address not only the relevance of what is being taught, but also how it is taught, universities need to avail both human and financial resources.

The following secondary objectives will assist in the achievement of the primary objective of this article:

- To identify the complexities associated with determining both the income and direct costs of presenting a module.

- To calculate the number of breakeven enrolments per teaching module at different NQF levels at the selected university.

- To identify the number of teaching modules at the selected university that have insufficient direct income to cover their direct costs.

- To provide universities with a costing methodology to potentially be able to avail human and financial resources to address these challenges.

\section{LITERATURE REVIEW}

\section{The Application of Cost Accounting at Traditional Universities}

COVID-19, the 4IR and the transition to online education, combined with declining student numbers, are impacting the very survival of traditional universities. Many experts are debating the problem, but few are facing the elephant in the room. Kotzee and Martin (2013, 624-629) 
are of the opinion that any conversation focusing on traditional universities and their funding should include a debate of the value, nature and the purpose of education at a university (Kotzee and Martin 2013, 624). Debating the role of a traditional university is of critical importance, but falls outside the scope of this article. What is unfortunately clear is that the days of traditional universities being everything to everybody have ended abruptly. The solution to this dilemma is not a simple one. It is clear that traditional universities are currently confronted with serious financial problems. The application of cost and management accounting at universities could provide critical information to ensure their survival.

More than two decades ago Cropper and Drury $(1996,1)$ already pointed out the need for research on the application of management and cost accounting at universities with the specific aim to focus on the levels of cross-subsidising. In addition, a review of the available literature of cost accounting applications at universities all over the world indicated a focus on ActivityBased Costing $(\mathrm{ABC})$. These studies investigated the application of $\mathrm{ABC}$ as a more appropriate way of assigning costs in a service organisation that is typically characterised by fixed and indirect costs (Evans 2004; Dragija and Lutilsky 2012; Sobańska and Kalinowski 2013; Sorros, Karagiorgos, Mpelesis 2017; Sisa, Siklosi and Szijarto 2018). Given the complexity and detail information needed to apply $\mathrm{ABC}$, all these studies aimed at costing degrees or programmes at a higher education institution were limited to a single department. The authors could not find any related research costing all the modules of a university to ascertain the levels of crosssubsidising at that institution.

This article aims to address the gap in available literature by developing a costing model to determine the cost of a teaching module at a traditional university. The literature review focuses on challenges encountered in the development of a relevant costing methodology.

\section{Challenges in the Application of Cost and Management Accounting Principles at Universities}

\section{Universities as Service Organisations}

Universities are service organisations (Kamal, Sweeney and Soutar 2015, 173-175) and therefore have the classic management accounting problem of not really having a direct causal relationship between costs (mostly fixed) and revenue (related to the number of students, tuition fees and subsidies). Cost accounting provides process and cost information that aid organisations in their decision-making (Mohr 2013,6). A significant concern for service entities is that they do not fit in with traditional costing systems originally designed for manufacturing organisations. Thus, applying conventional costing methodologies often lead to inaccurate 
costing data (Terzioglu and Chan 2013, 32; Gripper 1995, 22). Service entities do not fit in with traditional cost accounting systems, given the lack of a clear input-output relationship in the delivery of services due to the primarily intangible nature of a service (Terzioglu and Chan 2013, 30). The following three characteristics of a service organisation are further challenges to the costing of services namely a) most costs are period (fixed) costs; b) there is typically not a causal relationship between period costs and output; and c) these organisations are usually labour intensive with most of the labour costs fixed, at least in the short to medium term (Terzioglu and Chan 2013, 32).

Gripper $(1995,27)$ extends the difficulties surrounding the input versus output of a service by stating that the cost objective of a service organisation (output) relies in differing measures on support activities (input), which can be difficult to pin down. The same characteristics are prevalent at universities with the majority of costs being discretionary and committed fixed costs (Moore 1998, 76; Szychta 2010, 49; Statistics South Africa 2017, 6). The gap in the theory addressed in this research is to provide a unique costing methodology for the main services (teaching modules) of universities.

\section{Quantifying the Level of Cross-subsidy}

Attempting to measure the extent of cross-subsidy at universities face several challenges. Firstly the choice of what to use as a cost centre. Possible cost centres range from modules, to departments to faculties (Lewis and Pendlebury 2002, 26). The second challenge is the possible resistance from academics to quantify the existing cross-subsidy related to the perception that this would allow dominance of "traditional academic values" by financial objectives. The profit motive is of very little importance in the traditional essence of universities which is focused on serving society and the economy (Lewis and Pendlebury 2002, 27).

A university has a further difficulty due to the diversity of specifically the teaching services delivered (Terzioglu and Chan 2013,32). The university related to this study presented 3689 teaching modules, with 286831 students enrolled in 2018. These modules further represent a wide range of credits and are presented at five different National Qualifications Framework (NQF) levels. The modules are also funded at 12 different funding weights by the South African Government. In a typical manufacturing or retail environment, variable or product costs dominate with a direct causal relationship to outputs, which makes variable costing and budgeting much more relevant and accurate. The absence of a direct or causal relationship of costs to outputs, such as in most service organisations and universities, implies that conventional cost and management accounting methods are severely constrained. The lack of appropriate costing systems to cost a service is also the case when acquiring cost information 
for modules to assist with the decision-making process at universities (Serfontein 2019, 28$30)$.

\section{Current Funding Structure of South African Universities}

From the background to this study, it is clear that universities require funding to adapt to the changes required by COVID-19 and the 4IR. The current funding structure of universities creates a platform for financial uncertainty, since not all of the income is controllable by the universities. The steady decrease in government funding for higher education in South Africa since 2001 further increases the pressure universities face (Higher Education South Africa Task Team 2008, 10; Serfontein 2019, 83). Additional stress on the income streams of South African universities relates to decreased income from class fees due to the impact of the \#FeesMustFall campaign of 2015 (Editorial 2015; BBC 2016, par. 2; South African History Online 2016, par. $3)$.

The tertiary education environment in South Africa clearly accentuates that the current funding structure of universities in South Africa does not provide for additional funds to upscale the current skill set of academics or provide for the necessary changes to the higher education system as indicated in the background to this study. A further complication that inhibits the funding of upskilling academics and transforming the higher education sector is the costing structure of a university. Service organisations' operating expenses are almost completely committed and discretionary fixed costs that cannot easily be changed in the short term (Szychta 2010, 49). A university that delivers a service also has its main component of expenditure related to salaries, which is fixed in the short to medium term (Statistics South Africa 2018, 6). This implies that any change to the costing structure of a university will take time to have any effect. The research focus of this article, therefore, is on how traditional universities can redirect both their human and financial capacity to ensure that it remains relevant; thus, have the capacity to redesign both the content and methodology of teaching. The fixed and indirect nature of costs in a service organisation, combined with educational programmes typically taking three to five years to be phased out, highlight the time-consuming aspect and difficulty to avail these resources in the short term, as well as the sense of urgency to start the process as soon as possible.

\section{RESEARCH METHODOLOGY}

Understanding the organisational structure of the related university is the starting point in achieving the main purpose of this study, namely to develop a costing methodology to ascertain which teaching modules at a selected South African university are making a direct profit and 
which a direct loss. The related university functions from 133 departments within seven different faculties. Each of these departments has its own management structure with autonomous decision-making power.

It is clear that the selected university functions from a decentralised organisational structure, which brings the principle of Responsibility Accounting (RA) into effect (Owino $2017,2)$. The principle of RA is that the individual responsible for incurring the expenditure, controls the expenditure (Owino, Munene, and Ntayi 2016, 2; Anitsal, Mahmud, and Anitsal 2018, 85). RA also brings the concept of responsibility centres into the equation. A responsibility centre can be a unit or subunit of any organisation (Owino et al. 2016, 2; Anitsal, Mahmud, and Anitsal 2018, 87). An organisation can function from four types of responsibility centres; revenue, cost, profit and/or investment (Anitsal, Mahmud, and Anitsal 2018, 85). The discussion of these responsibility centres is, however, outside the scope of this article.

Suffice to say, departments at universities can be classified as profit centres. The reasons for this classification are that the heads of departments are responsible for increasing student numbers (therefore increasing revenue) and for controlling costs (operating budget as well as the number of personnel (SLE's)) (University of the Free State 2013, 1-87; University of Cape Town n.d., par. 9). The breakeven point for a module becomes a very noteworthy figure from a cost management point of view, since this figure indicates the point at which a department is presenting a module that will, at a minimum, cover its direct costs, but not necessarily making a profit (Drury 2018, 172). The breakeven point of sale is calculated as follows:

\section{Equation 1: Breakeven point}

In the above equation:

$$
B E=F /(P-V)
$$

$\mathrm{F}=$ Total fixed costs

$\mathrm{P}=$ Sales price per unit

$\mathrm{V}=$ Variable cost per unit

When a teaching module is considered to be the cost objective, enrolments become the "units" generating revenue and incurring costs. The breakeven number of enrolments per module will, therefore, be calculated to evaluate the performance of a department as follows:

\section{Equation 2: Breakeven enrolments per module}

$$
B E=F /(P-V)
$$

In the above equation:

$\mathrm{F}=$ Mean fixed teaching costs per 16-credit weighted module. 
$\mathrm{P}=$ Mean teaching income per enrolment per 16-credit weighted module.

$\mathrm{V}=$ Mean variably allocated direct costs per enrolment per 16-credit weighted module.

Applying equation 2 is, however, not straightforward. Table 1 reveals the building blocks of the costing structure at a university.

Table 1: Methodology of costing teaching modules at a South African university

\begin{tabular}{|c|c|c|c|c|}
\hline \multicolumn{5}{|c|}{ Statement of Teaching-Related Profit and Loss for the University for the year 2017} \\
\hline & $\begin{array}{r}\text { University } \\
\text { Total } \\
\end{array}$ & $\begin{array}{r}\text { Individual } \\
\text { Faculty } \\
\end{array}$ & $\begin{array}{r}\text { Individual } \\
\text { Department }\end{array}$ & $\begin{array}{r}\text { Individual } \\
\text { Module }\end{array}$ \\
\hline Teaching Income & $\mathbf{X X}$ & $\mathbf{X X}$ & $\mathbf{X X}$ & $\mathbf{X X}$ \\
\hline Tuition Fees & $\mathrm{Xx}$ & $\mathrm{xx}$ & $x \mathrm{x}$ & $x \mathrm{x}$ \\
\hline Teaching Input Subsidy & $\mathrm{Xx}$ & $\mathrm{xx}$ & $\mathrm{xx}$ & $\mathrm{xx}$ \\
\hline Direct Costs & $\mathbf{X X}$ & $\mathbf{x X}$ & $\mathbf{x X}$ & $\mathbf{x X}$ \\
\hline Allocated on a Fixed basis & $\mathrm{Xx}$ & $\mathrm{xx}$ & $x \mathrm{x}$ & $x x$ \\
\hline Allocated on a Variable basis & $\mathrm{Xx}$ & $\mathrm{xx}$ & $\mathrm{xx}$ & $\mathrm{xx}$ \\
\hline Contribution / Direct Profit & $\mathbf{x x}$ & $\mathbf{x X}$ & $\mathbf{x x}$ & $\mathbf{X X}$ \\
\hline Indirect Costs & $\mathbf{X X}$ & $\mathbf{X X}$ & $\mathrm{XX}$ & $\mathbf{x X}$ \\
\hline Allocated based on Teaching Income & $X x$ & $x x$ & $x x$ & $x x$ \\
\hline Allocated based on Direct Costs & $\mathrm{Xx}$ & $x x$ & $x \mathrm{x}$ & $\mathrm{xx}$ \\
\hline Profit/Loss & $x x$ & $\mathbf{x x}$ & $x x$ & $\mathbf{x x}$ \\
\hline
\end{tabular}

Table 1 indicates the various building blocks that influence the income and costs related to a module. It is important to note that the behaviour of the costs identified in Table 1 will vary depending on the cost objective identified (university, faculty, department or module). Only the direct teaching costs per faculty were utilised in this study; and accordingly, various discretionary decisions were made to enable the costing of an individual module and eventually the calculation of a breakeven point per module, as discussed in sections 4.1 and 4.2. The direct teaching costs represent less than 35 per cent of the total direct and indirect costs of the selected university; thus do not represent a true breakeven of modules at all (the actual breakeven enrolments per module, if full costs are recovered, will be much higher than presented in this research).

\section{Calculation of teaching income}

The teaching income $(\mathrm{P})$ utilised in the breakeven calculation (refer to equation 2) takes the tuition fee income as well as the teaching input subsidy received from the government into account. The actual tuition fees for the 2018 academic year was obtained from the Finance Department at the said university. The subsidy portion of the teaching income was derived using the actual teaching input units (TIUs) as received from the Department of Higher Education, 
Science and Technology and calculated using HEMIS data. The teaching income per enrolment utilised in equation 2 was calculated as follows:

\section{Equation 3: Standard teaching income per enrolment $(P)$}

\section{Standard teaching income per module}

$$
=\text { Total teaching income per module/enrolments per } 16 \text { credit weighted module }
$$

\section{Calculation of the cost of teaching modules}

As mentioned in the literature review of this study, the costing of a service comes with a variety of challenges. One of the mentioned challenges relates to the lack of causality between input and output. This challenge is even more severe in a university environment, as is the case in this study. The total cost related to teaching modules at the selected university consists of both direct (personnel costs and operating budget) and indirect costs (such as maintenance, electricity and various staff and support departmental costs). The focus of this study was on assigning only the direct costs related to teaching modules as incurred by the university to the individual modules.

The government grant (subsidies) received by the related university is allocated to each faculty in the form of an SLE (Senior Lecturer Equivalent). Faculties allocate these costs to the departments within the faculty based on the number of student enrolments, research outputs per department as well as the discretion of the faculty management. The departments spend the allocated funds primarily on salaries (a fixed/period cost). The salary cost, therefore, forms part of the direct expenditure if the faculty is regarded as the cost objective. The operating budget per faculty also forms part of the direct costs of the university (if a faculty is seen as the cost objective). However, due to the discretion involved in allocating the SLEs and operating budget to departments, these costs become indirect if a department is regarded as the cost objective. The assignment of the government grant to faculties is not influenced by the number of modules presented by the faculty. The direct cost, therefore, behaves as a fixed cost with regards to modules as the cost objective (this cost will be influenced by the number of enrolments over time, but not the number of modules). This cost must be allocated to individual modules, which causes the cost to be regarded as an indirect cost when an individual module is the cost objective. Because an indirect cost cannot be directly traced to the related cost objective, discretion is required in allocating these costs to the cost objective (Gordon and Loeb 2001, 13; Novák et al. 2017, 76; Drury 2018, 24).

Since there is no direct causal relationship between the cost incurred by a faculty and the cost objective (a teaching module), the following discretionary decisions were made to enable 
the allocation of these costs to individual modules:

- Only 60 per cent of faculty direct costs were allocated to the teaching modules in the faculties. As stated earlier in this section, the focus of this study is on teaching modules only. However, a university performs three primary functions, i.e. teaching, supervision of Honours, Master's and Doctoral students (mini-dissertation, scripts and theses), as well as research. The direct costs of a university provide for the performance of all three activities, of which 60 per cent is regarded as the costs required to perform the teaching function. According to the selected university's financial statements, as much as 75 per cent of the total income received by the university represented teaching income. HEMIS data for the selected university indicated that academics spend 51 per cent of their time on teaching-related activities. The workload model of the same university revealed that 55 per cent of academics' time was spent on teaching activities. Based on these three indicators, it appeared that 60 per cent could be regarded as a conservative estimate of the percentage of direct costs associated with delivering teaching activities at the selected university.

- $\quad$ As much as 80 per cent of direct teaching costs were allocated to modules on a fixed basis with the number of modules as the cost driver $(F)$, while 20 per cent of direct teaching costs could be associated with the size of the module; thus, allocated on a variable basis with the number of enrolments per 16-credit weighted module as the cost driver $(V)$. When the behaviour of costs are considered, the cost objective must be clearly identified. This study focuses on the costing of teaching modules. An individual teaching module is consequently considered to be the cost objective. As mentioned earlier in this section, most direct costs behave in a fixed manner with regards to modules as the cost objective. However, there are certain costs involved in the delivering of modules that will increase with an increase in enrolments, since it could, amongst others, lead to a repetition of lectures, additional marking costs and increased consultation hours $(20 \%$ of the direct teaching costs). It is also recognised that most of the effort in presenting a module - such as preparation of study material, preparing lectures and setting of tests and examinations - are fixed, irrespective of the number of enrolments ( $80 \%$ of the direct teaching costs).

The literature review of this article highlighted the diversity of the services delivered by the related university (that is, in terms of teaching modules). As explained earlier in this section, certain discretionary decisions were made to standardise the calculation of the cost per module. The possible drivers identified complicating standardisation were the number of enrolments, 
NQF levels, number of credits per module and government-subsidy funding weights. The calculations performed in determining the breakeven number of enrolments per module were used to determine certain statistical relationships in order to arrive at the best possible driver for module-related profitability.

\section{RESULTS AND FINDINGS}

Traditional universities worldwide, and specifically in South Africa, are at a crossroads. Students are complaining about rising tuition fees; the SA government is finding it difficult to subsidise both the universities and the disadvantaged students (NSFAS). In addition, the 4IR is posing serious challenges regarding both the content of what is taught as well as the mode of delivery. Invariably, academic staff will need to be retrained in terms of both what and how to teach with COVID-19 accelerating the process. Within such an environment, it is critical to find the necessary funding to finance the required, radical changes. The question addressed in this research is thus whether South African universities potentially have the capacity to generate both human and financial resources to effect these much-needed changes and address the challenges. The focus of this study is primarily on teaching modules (thus excluding research modules from the population). From Table 2, it is clear that the sample of 3689 teaching modules at the selected university comprises 89,5 per cent of the total teaching income and 93,2 per cent of all enrolments.

Table 2: Population versus Sample of Teaching Modules

\begin{tabular}{|l|r|r|c|}
\hline & Population & Sample & Sample \% \\
\hline Modules & 4259 & 3689 & 86,6 \\
Enrolments & 307690 & 286831 & 93,2 \\
\hline Tuition (R'000) & 1034733 & 957234 & 92,5 \\
Subsidy (R'000) & 951466 & 821334 & 86,3 \\
\hline Total ('000) & $\mathbf{1 9 8 6 1 9 8}$ & $\mathbf{1 7 7 8 5 6 8}$ & $\mathbf{8 9 , 5}$ \\
\hline
\end{tabular}

Table 3 compares under- and postgraduate modules and enrolments. Universities typically promote postgraduate studies with the intent to increase research outputs. The common belief is also that postgraduate modules are more profitable because of the higher levels of government subsidies related to higher NQF levels. At the selected university, it was established that 34,4 per cent of the modules presented were postgraduate, but represented only 9,2 per cent of the enrolments. In addition, undergraduate modules on average had 107,7 enrolments while postgraduate modules had 20,7 enrolments per module. 
Table 3: Enrolments and Modules: Under- versus Postgraduate

\begin{tabular}{|l|c|c|c|c|c|}
\hline & Total & Undergrad. & Postgrad. & \%UG/Tot & \%PG/Tot \\
\cline { 1 - 4 } Enrolments & 286831 & 260502 & 26329 & 90,8 & 9,2 \\
Modules & 3689 & 2419 & 1270 & 65,6 & 34,4 \\
\cline { 1 - 4 } Enrol/Module & $\mathbf{7 7 , 8}$ & $\mathbf{1 0 7 , 7}$ & $\mathbf{2 0 , 7}$ & \\
\cline { 1 - 3 } Significance (ANOVA) & \multicolumn{3}{|c|}{$0.000^{* *}$} \\
\cline { 1 - 3 }
\end{tabular}

The researchers applied the principle that all NQF 5, 6 and 7 modules are undergraduate and that the majority of NQF 8 and 9 modules are postgraduate. Table 4 confirms that the subsidy income per enrolment for postgraduate modules are significantly $\left(\operatorname{sig}=0,000^{* *}\right)$ higher than for undergraduate modules. What is, however, interesting to note is that tuition income per enrolment shows little change for under- versus postgraduate modules. Thus, the government recognises that it is more expensive to present postgraduate modules (given government subsidies per module), but not the management of the selected university. If the university intends to attract postgraduate students, this approach of low tuition fees for postgraduate studies makes sense, but not from a financial perspective - which is the focus of this research study.

Table 4: Subsidy versus Tuition Income per Weighted Module

\begin{tabular}{|l|c|r|r|c|}
\hline \multirow{2}{*}{ Grad. Level } & \multicolumn{3}{|c|}{ Income per Weighted Enrolment } & \multirow{2}{*}{ Subsidy/Teaching } \\
\cline { 2 - 4 } & Subsidy & Tuition & Teaching & \\
\hline NQF5-7 & 2438 & 3220 & 5658 & $43,10 \%$ \\
NQF8 & 4866 & 3571 & 8437 & $57,68 \%$ \\
NQF9 & 7750 & 2992 & 10741 & $72,15 \%$ \\
\hline Total & $\mathbf{2 7 9 3}$ & $\mathbf{3 2 5 6}$ & $\mathbf{6 0 4 9}$ & $\mathbf{4 6 , 1 8 \%}$ \\
\hline Significance & \multicolumn{3}{|c|}{$\mathbf{0 , 0 0 0}^{* *}$} \\
\hline
\end{tabular}

The breakeven enrolments per module is presented in Table 5. In the initial costing model on which this study is based, the fixed and variable costs for the individual modules were calculated based on the financial information per faculty. However, for this research, the data for both the fixed cost per module and variable cost per enrolment were calculated using total direct teaching costs and income for the selected university, as well as all weighted modules and enrolments with the intent to simplify the interpretation of the results from this study. Although this approach leads to small changes regarding individual modules, the detailed picture is very similar. Table 5 shows that the fixed costs of presenting a module are R136 981, while the variable cost for each additional enrolment is R478. Using these parameters, it was established that, on average, the selected university needs 24,6 enrolments per module to recover the direct cost of presenting it. As was expected, given the higher subsidies per 
enrolment for postgraduate modules, undergraduate modules need 26,4 enrolments, while NQF 8 modules need 17,2 enrolments and NQF 9 modules only 13,3 enrolments to cover the direct costs.

Table 5: Calculation of Breakeven Enrolments per Module at various NQF Levels

\begin{tabular}{|l|c|c|c|c|}
\hline Grad. Level & $\begin{array}{c}\text { Fixed Cost/ Wght. } \\
\text { Module }\end{array}$ & $\begin{array}{c}\text { Income/Wght. } \\
\text { Enrol }\end{array}$ & $\begin{array}{c}\text { Variable cost/Wght. } \\
\text { Enrol }\end{array}$ & Breakeven \\
\hline NQF5-7 & 136981 & 5658 & 478 & 26,4 \\
NQF8 & 136981 & 8437 & 478 & 17,2 \\
NQF9 & 136981 & 10741 & 478 & 13,3 \\
\hline Total & $\mathbf{1 3 6 9 8 1}$ & $\mathbf{6 0 4 9}$ & $\mathbf{4 7 8}$ & $\mathbf{2 4 , 6}$ \\
\hline
\end{tabular}

In Table 6, all the modules at the various NQF levels were classified into three groups, namely those having a negative direct profit $(\mathrm{DP}<0)$; those having a positive direct profit of less than R1 million per module (DP 0-1m.); and those having a direct profit in excess of R1 million per module (DP $>1 \mathrm{~m}$.). The direct profit per module was calculated by adding both the subsidy and tuition income per module and subtracting both the fixed and variable direct costs for the related module from it. Of the 3689 teaching modules included in the sample, as many as 1768 are not recovering their direct costs. Thus, slightly more than half of the modules presented at the selected university are cross-subsidising 47,9 per cent of the teaching modules. Another important observation is that only 39,6 per cent of undergraduate modules are not recovering their direct costs, as opposed to 59,2 per cent and 76,9 per cent of modules at NQF levels 8 and 9, respectively. Thus, the postgraduate situation is substantially worse from a financial point of view. We can deduce that, irrespective of the higher levels of subsidies for NQF 8 and 9 modules (see Table 4), the low levels of enrolments for postgraduate modules (see Table 3) do not compensate sufficiently to recover the direct costs of presenting them.

Table 6: Number of Modules not recovering their Direct Costs

\begin{tabular}{|l|c|c|c|c|c|c|c|}
\hline \multirow{2}{*}{$\begin{array}{l}\text { Grad. } \\
\text { Level }\end{array}$} & \multicolumn{3}{|c|}{ Number of Modules } & \multicolumn{3}{c|}{ \% of Modules } \\
\cline { 2 - 4 } \cline { 7 - 8 } & DC $<$ & DC $\mathbf{0 - 1} \mathbf{m}$. & DC > 1 $\mathbf{~ m . ~}$ & Total & DC < 0 & DC 0-1m. & DC > 1 $\mathbf{~ m . ~}$ \\
\hline NQF5-7 & 958 & 1144 & 316 & 2418 & 39,6 & 47,3 & 13,1 \\
NQF8 & 560 & 342 & 44 & 946 & 59,2 & 36,2 & 4,7 \\
NQF9 & 250 & 73 & 2 & 325 & 76,9 & 22,5 & 0,6 \\
\hline Total & $\mathbf{1 7 6 8}$ & $\mathbf{1 5 5 9}$ & $\mathbf{3 6 2}$ & $\mathbf{3 6 8 9}$ & $\mathbf{4 7 , 9}$ & $\mathbf{4 2 , 2}$ & $\mathbf{9 , 8}$ \\
\hline
\end{tabular}

- DP-Direct Profit (per Module $)=($ Tuition + Subsidy Income $)-($ Total Direct Fixed per module + Total Direct Variable Costs per module)

Top management of traditional universities often defend their independence, stating that they want full autonomy regarding what programmes are required and what modules are to be 
presented. One of the main characteristics of a traditional university is also public service with certain modules being presented only to fulfil a university's social responsibility, as required by the related community (Perkins 1973, 3-12; Etzkowitz et al. 2000, 313; Walton and Martin 2004, 11; Bikse et al. 2016, 76). However, the 1769 modules not covering their direct costs (see Table 6) had only 5,2 per cent of all enrolments (see Table 7). Hence, if the selected university had to close 47,9 per cent of the modules not covering their direct costs, it would only impact 14867 of 286832 enrolments, which is negligible. The question remains whether not presenting these loss-making modules would have any real impact on skills needed in the market. If we focus only on undergraduate modules (Table 6) and enrolments (Table 7), the 959 modules with negative direct profits had only 10753 enrolments, while the undergraduate modules (316) with direct profits in excess of R1 million had 153795 enrolments.

Table 7: Number of Enrolments in Modules not recovering their Direct Costs

\begin{tabular}{|c|c|c|c|c|c|c|c|}
\hline \multirow{2}{*}{$\begin{array}{l}\text { Grad. } \\
\text { Level }\end{array}$} & \multicolumn{3}{|c|}{ Enrolments per Category } & \multirow{2}{*}{ Total } & \multicolumn{3}{|c|}{$\%$ of Enrolments } \\
\hline & $\mathrm{DC}<0$ & DC 0-1mil. & DC>1 mil. & & $\mathrm{DC}<0$ & DC0-1mil. & DC > 1 mil. \\
\hline NQF5-7 & 10753 & 95954 & 153795 & 260502 & 4,1 & 36,8 & 59,0 \\
\hline NQF8 & 2995 & 13169 & 7265 & 23429 & 12,8 & 56,2 & 31,0 \\
\hline NQF9 & 1119 & 1684 & 98 & 2901 & 38,6 & 58,0 & 3,4 \\
\hline Total & 14867 & 110807 & 161158 & 286832 & 5,2 & 38,6 & 56,2 \\
\hline
\end{tabular}

Table 8 illustrates the severity of the situation at the selected university from a financial perspective. Of the total of 3689 teaching modules, 1769 (or 47,9\%) (see Table 6) have a total negative direct profit (loss) of R187,1 million. In contrast, the 362 modules $(9,8 \%)$ (see Table 6) in the R1 million+ category have a total direct profit of R864,1 million. Thus, about 47,9 per cent of the modules presented at the selected university have a direct loss of R187,1 million, while the other 52,1 per cent have a direct positive profit of R1 262,9 Million.

Table 8: Direct Profitability per category of Modules

\begin{tabular}{|l|c|c|r|r|}
\hline \multirow{2}{*}{$\begin{array}{l}\text { Grad. } \\
\text { Level }\end{array}$} & \multicolumn{3}{|c|}{ Direct Profit per Category (R) } & \multirow{2}{*}{ Total } \\
\cline { 2 - 4 } NQF5-7 & -69756069 & DC 0 - 1 mil. & DC > 1 mil. & 1 027027750 \\
NQF8 & -65338070 & 71346383406 & 782420413 & 85253419 \\
NQF9 & -52043468 & 13030105 & 79245106 & -36544195 \\
\hline Total & $\mathbf{- 1 8 7 1 3 7 6 0 7}$ & $\mathbf{3 9 8 7 3 9 8 9 4}$ & $\mathbf{8 6 4 1 3 4 6 8 7}$ & $\mathbf{1 0 7 5 7 3 6 9 7 4}$ \\
\hline
\end{tabular}

The financial results in Table 8 do not take the indirect costs of running the selected university into account. By using the direct profit, it also assumes that the income of the enrolments will be lost if the modules are not presented. If we take the indirect costs of running the university 
into account, the selected university could save in excess of R400 million or 18,2 per cent of its total costs by not presenting the modules with a negative direct profit.

From the analyses it transpires that the responding university could save a substantial amount of money by critically assessing the current modules being presented. University officials often argue that their primary function is to render a service to the country and their community and that profitability is not a strategic issue. However, if there is little need (in terms of the number of enrolments) for the lossmaking modules, the question can be asked as to what their value to the community really involves.

The potential strategic value of this research article is not to turn a university into a profitmaking business, but a) to assist faculties and departments in optimising the use of both human and financial resources; b) to create stakeholder awareness of the level of cross-subsidising of modules at all levels; c) to provide top management with accurate financial information to make strategic decisions (such as size and shape discussions); d) to potentially be able to lower tuition costs to students; and e) to avail human capacity to increase research outputs. The literature review of this article highlighted the diversity of the services delivered by the related university (focusing only on teaching modules). As explained earlier in this section, certain discretionary decisions were made to simplify the calculation of the cost per module. However, if we truly want to measure the performance of a department in view of assisting in the decision-making process as aimed by this research, the real drivers of the profitability of modules must be considered. The possible drivers identified are the number of enrolments and credits, NQF levels, and government subsidy funding weights. Table 9 provides insight into enrolments, credits, NQF levels and funding weight as possible drivers of the direct profit of a module at the selected university.

Table 9: Correlation Matrix between the Direct Profit, Module Enrolments, Credits, NQF Levels and Funding Weights

\begin{tabular}{|l|c|c|}
\cline { 2 - 3 } \multicolumn{1}{c|}{} & \multicolumn{2}{c|}{ Direct Profit } \\
\hline Factors: & Pearson Correlation & Sig.(1-tailed) \\
\hline Module enrolments & 0.852 & $0.000^{* *}$ \\
\hline NQF & -0.227 & $0.000^{* *}$ \\
\hline Funding Weight & -0.046 & $0.003^{* *}$ \\
\hline Credits & -0.048 & $0.002^{* *}$ \\
\hline
\end{tabular}

${ }^{* *}$ Correlation significant at the 0.01 level (1-tailed)

Table 9 indicates that there exists a significant difference between the direct profit of a module and the number of students enrolled, credits assigned, NQF level as well as the funding weight 
of the module. However, the strength and direction of the correlation between the direct profit and the variables identified vary. The first variable explored in Table 9 as a possible main driver of the direct profit of a module is the number of enrolments. Table 9 indicates that there is a very strong, positive correlation between the number of students enrolled in a module and the direct profit of that module (0.852). This appears to be the only positive correlation, since the correlation amongst all the other variables and the direct profit per module have a negative and relatively weak relationship.

The very strong and positive correlation between the number of students enrolled in a module and the direct profit of the module focuses the conversation on the biggest driver of the financial viability of modules to be the number of enrolments in the related modules. The $\mathrm{R}$ Square $(0,732)$ also indicated that 73,2 per cent of the direct profits of a module is influenced by the number of enrolments. The findings in Table 9 also confirm that the breakeven number of enrolments provides a valuable tool in examining the direct profitability of a module.

\section{CONCLUSION}

This study aims to address the disruptive challenges universities are facing by focusing on teaching modules at a selected South African university from a cost accounting and financial viability perspective. Many experts are predicting the demise of most traditional universities emanating from the 4IR and accelerated by COVID-19. However, almost nothing is said about how the problem can be solved. Financial resources are needed to refocus the skillset students need, to retrain academic staff, to deal with declining student numbers and to embrace online learning. The researchers acknowledge that universities should always have academic freedom in deciding what to present; there will always be programmes and modules that have strategic value. Thus, there will always be a certain level of cross-subsidising of modules (Lewis and Pendlebury 2002, 36). The research questions are, however, do universities comprehend the levels of cross-subsidising of teaching modules, and can they afford it in this disruptive environment?

The size of the sample consisting of 3689 teaching modules and 286831 enrolments, combined with the challenges of costing a service organisation - specifically if the services delivered are not uniform - highlight the complexity and the unique contribution of the research. Modules are presented in different faculties, at various NQF levels, with a different number of credits and at various funding weights (Saladrigues and Tena 2017, 120). A limitation encountered was that the focus of this study was on teaching modules only and not on the costing of departments, faculties or research modules. However, the researchers believe that teaching modules garner the highest income and also incur the largest portion of the 
expenditure of most universities.

At the selected university, almost half of the modules have a direct loss of R187,1 million, while only 362 (9,8\%) modules generated a direct profit of R864,1 million. Although traditional universities seldom have a primary profit motive, these levels of crosssubsidising are truly questionable from a financial point of view. The fact that only one responding university was included in this study may be regarded as a limitation, but the authors are convinced that similar scenarios are prevalent at most traditional universities. The focus is also on the sustainability of traditional universities from a financial perspective, not taking the academic or strategic importance of certain disciplines into account.

All indications are that universities need to face these stark realities. The option to be a typical traditional university seems not to be sustainable any more. The starting point to the survival of these institutions must be to challenge the relevance and financial viability of modules, departments, faculties and even certain universities. These cost savings could be used to avail human capacity for retraining staff to embrace the demands of the 4IR (both in terms of what is taught as well as how it is presented), to fund online education and/or to support relevant research outputs. Another option would be to lower tuition fees, increasing the affordability to the unemployed and poor.

The consequences of these proposals are potentially devastating to academics and science, but is there any other solution? The question remains whether most traditional universities can keep on increasing tuition fees while demanding more government subsidies, be oblivious to the levels of cross-subsidising in their institutions, and in doing so, ignore the needs of their primary target market for more affordable education to ensure employability? Making these crucial strategic decisions to address the critical external and internal challenges that most universities are facing, require brave and bold strategic decisions as well as relevant and accurate financial (costing) information. The main emphasis with this research study was to make universities aware of their levels of cross-subsidising and provide them with a cost accounting methodology to assist in decision-making to ensure financial sustainability.

Jim Collins (2009) in his book "How the Mighty Fall" emphasised "Denial of Risk and Peril" as one of the stages of decline. Those who think COVID-19 is a short-term problem not fast-tracking the inevitable 4IR and ignoring its long-term consequences, are avoiding reality. "Business as usual" is not an option. Many industries in the past few decades have been completely disrupted by technology and it seems naïve to think this is not currently affecting traditional universities. Unless universities totally re-imagine their future, focusing on modules, departments and faculties to ensure relevance, affordable education and financial sustainability, most traditional universities could be facing extinction. The disruptive transformation 
traditional universities are confronted with requires radical strategies. The researchers are convinced that the unique cost and management accounting methodology applied in this study provides the much needed approach to assess existing activities and to ensure survival. Attempting to do more with less will be financial suicide over the medium-term in this disruptive environment.

\section{REFERENCES}

Adams, Richard. 2020. "UK Universities Facing Possible Financial Disaster, Research Says." The Guardian July 6.

Adendorff, C., U. Lutshaba, and A. Shelver. 2018. Policy Implications of the 4th Industrial Revolution for the Cultural and Creative Economy. Port Elizabeth: Nelson Mandela University.

Anitsal, M. M., I. Mahmud, and I. Anitsal. 2018. "Revisiting Responsibility Accounting: What are the relationships among responsibility centers?" Global Journal of Accounting and Finance 2(1): 8498.

$B B C$. 2016. "Why Are South African Students Protesting?" BBC October 4.

Bikse, V., I. Lusena-Ezera, B. Rivza, and T. Volkova. 2016. "The transformation of traditional universities into entrepreneurial universities to ensure sustainable higher education." Journal of Teacher Education for Sustainability 18(2): 75-88.

Collins, J. 2009. How the Mighty Fall and Why Some Companies Never Give In. London: Random House Business Books.

Cropper, P., \& Drury, C. (1996). Management accounting practices in universities. Management Accounting: Magazine for Chartered Management Accountants 74(2): 28-30.

Davies, M. 2012. “Can universities survive the digital revolution?" Quadrant 56(12): 58-66.

Dragija, M. and I. D. Lutilsky. 2012. "Activity-Based Costing as a Means to Full Costing-Possibillites and Constraints for European Universities." Management 17(1): 33-57.

Drury, C. 2018. Management and Cost Accounting. 10th ed. Hampshire: Cengage Learning EMEA.

Editorial. 2014. "The Digital Degree - The Future of Universities." The Economist July 27.

Editorial. 2015. "Government Committed to Find Zero Fees Funding: Nzimande." ENCA November 4.

Editorial. 2020. "Public Universities Have Either Embraced Emergency Teaching/Learning, or Are Getting Ready for the Inevitable, in the COVID-19 Era." https://www.usaf.ac.za/universitiescoronavirus-covid-19-updates/ (Accessed 12 June 2020).

Ehlers, U. 2020. Future Skills. Karlsruhe: Springer.

Etzkowitz, H., A. Webster, C. Gebhardt, and B. R. C. Terra. 2000. "The future of the university and the university of the future: Evolution of ivory tower to entrepreneurial paradigm." Research Policy 29(2): 313-30.

Evans, T. M. 2004. "Activity-Based Costing at Colleges and Universities: Understanding, Communicating and Controlling Costs Associated with Educating Different Student Groups." Ph.D. dissertation. University of Texas.

Gordon, L. A. and M. P. Loeb. 2001. "Distinguishing between direct and indirect costs is crucial for internet companies." Management Accounting Quarterly 1(Summer): 12-18.

Gripper, A. L. 1995. "An Examination of the Application of Activity-Based Costing in the Service Sector: A Descriptive Study." Ph.D. thesis. Walden University.

Hattingh, S. 2016. Skills Planning for the Unpredictable, Disruptive Fourth Industrial Revolution. Pretoria: LPI. 
Hess, A. 2018. "HBS Prof Says 50\% of US Colleges Will Be Bankrupt in 10 to 15 Years." CNBC August 30. https://www.cnbc.com/2018/08/30/hbs-prof-says-half-of-us-colleges-will-be-bankrupt-in-10to-15-years.html?_source=facebook\% 7 Cmain.

Higher Education South Africa Task Team. 2008. Tuition Fees Report. Higher Education South Africa. Jackson, W. 2015. “Adapt or Die: The 5 Keys to Disruptive Thinking." Human Resources 20(2): 4-6.

Kamal Basha, N., J. C. Sweeney, and G. Soutar. 2015. "Effects of Country and Delivery Mode on Perceived Risk in International Higher Education." Journal of Marketing for Higher Education 25(2): 171-203.

Kotzee, B. and C. Martin. 2013. "Who Should Go to University? Justice in University Admissions." Journal of Philosophy of Education 47(4): 623-641.

Lewis, B. and M. Pendlebury. 2002. "Surplus or Deficit - Who Cares? Cross-Subsidy in Colleges of Higher Education." Financial Accountability \& Management 18(1): 25-38.

Menon, K. and G. Castrillon. 2019. "Universities Have 'Pivotal Role' to Play in Fourth ...." Daily Maverick April 15. https://www.dailymaverick.co.za/article/2019-04-15-universities-havepivotal-role-to-play-in-fourth-industrial-revolution/.

Mesquita, A., P. Peres, and B. Xing. 2015. Furthering Higher Education Possibilities through Massive Open Online Courses. Chocolate Avenue, Hershey, PA: IGI Global.

Mohr, Z. T. 2013. "Cost Accounting in US Cities: Transaction Costs and Governance Factors Affecting Cost Accounting Development and Use." Ph.D. dissertation. University of Kansas.

Moore, D. H. 1998. "A Comparative Evaluation of Financial and Activity-Based Cost Accounting Systems in a Private University.” Ph.D. dissertation. Texas Tech.

Novák, P., B. Popesko, J. Dvorský, and J. Strouhal. 2017. "Analysis of Overhead Cost Behaviour: Case Study on Decision-Making Approach.” Journal of International Studies 10(1): 74-91.

Omarjee, L. 2018. "Reskilling a Priority to Prepare Workers for the Fourth Industrial Revolution." Fin24 October 7. https://m.fin24.com/Economy/Labour/reskilling-a-priority-to-prepare-workers-forthe-fourth-industrial-revolution-report-20181007.

Ostashewski, N., J. Howell, and J. Dron. 2017. "MOOCifying courses: Delivery of a MOOC to enhance university course activities." Journal of Learning for Development - JL4D 4(2): 184-95.

Owino, P. 2017. "The current status of responsibility accounting in Ugandan public universities." Donnish Journal of Business and Finance Management Research 3(1): 1-8.

Owino, P., J. C. Munene, and J. M. Ntayi. 2016. "Does Responsibility Accounting in public universities matter?" Cogent Business and Management 3(1): 1-10.

Perkins, J. A. 1973. The University as an Organisation. Edited by McGraw-Hill Book Company. California: Campanella, Joe.

Prifti, L. 2019. "Professional Qualification in 'Industrie 4.0': Building a Competency Model and Competency-Based Curriculum." Ph.D. dissertation. Technical University of Munich.

Roy, A. 2020. "The Pandemic Is a Portal." Financial Times April 3.

Saladrigues, R. and A. Tena. 2017. "Cost Accounting in Spanish and Catalan Universities: Its Current Status of Implementation." Intangible Capital 13(1): 117-46.

Schleicher, A. 2018. "Valuing our teachers and raising their status: How communities can help." In International Summit on the Teaching Profession. Paris: OECD Publishing.

Schwab, K. n.d. "The Fourth Industrial Revolution." World Economic Forum. https://www.weforum.org/about/the-fourth-industrial-revolution-by-klaus-schwab. (Accessed 28 November 2019).

Serfontein, C. 2019. "Financial Viability - Costing Teaching Modules at a South African University." Master's thesis. University of the Free State.

Shah, D. 2018. "By the numbers: MOOCs in 2018." Class Central December 11. https://www.classcentral.com/report/mooc-stats-2018/. 
Sisa, K., A. Siklosi, and B. Szijarto. 2018. "Cost Accounting in Hungarian Public Higher Education Institutions." Research Papers of Wroclaw University of Economics 515: 278-85.

Sobańska, I. and J. Kalinowski. 2013. "Cost Management in European Universities - A Time of Change.” Kaštu Valdymas Europos Universitetuose: Laikas Keistis? 82(4): 84-93.

Sorros, J., A. Karagiorgos, and N. Mpelesis. 2017. "Adoption of activity-based costing: A survey of the education sector of Greece." International Advances in Economic Research 23: 309-320.

South African History Online. 2016. "Student Protests in Democratic South Africa." http://www.sahistory.org.za/article/student-protests-democratic-south-africa. (Accessed 12 August 2020).

Statistics South Africa. 2018. Financial Statistics of Higher Education Institutions. Pretoria: Statistics South Africa.

Statistics South Africa. 2017. Jump in Government Higher Education Spending. http://www.statssa.gov.za/?p=10652. (Accessed 13 June 2020).

Szychta, A. 2010. "Time-driven activity-based costing in service industries.” Social Sciences 1(67): 4961.

Terzioglu, B. and E. S. K. Chan. 2013. "Toward understanding the complexities of service costing: A review of theory and practice." Journal of Applied Management Accounting Research 11(2): 2944.

Ubell, R. 2010. Virtual Teamwork: Mastering the Art Practice of Online Learning and Corporate Collaboration. New York: Wiley.

University of Cape Town. n.d. "Headships of Academic Departments." http://www.hr.uct.ac.za/ $\mathrm{hr} /$ service/academic/roles/headships. (Accessed 6 June 2020).

University of the Free State. 2013. "University of the Free State General Institutional Rules and Regulations (First Qualifications)." https://www.ufs.ac.za/docs/default-source/admissionrequirements-and-general-regulations-documents/2013-1-general-institutional-rules-firstqualifications-1110-eng.pdf?sfvrsn=a46e421_0. (Accessed 13 June 2020).

Walton, J. S. and M. C. Martin. 2004. "Corporate universities versus traditional universities: Comparison through published organisation documentation." In Academy of Human Resource Development International Conference (AHRD), 10-17.

World Economic Forum (WEF). 2016. "The Future of Jobs: Employment, Skills and Workforce Strategy for the Fourth Industrial Revolution." https://doi.org/10.1177/1946756712473437 (Accessed 12 June 2020).

Yang, P., Y. Yanyue, B. E. Penprase, B. Xing, E. Muller, T. Marwala, C. Malpas, et al. 2018. Higher Education in the Era of the Fourth Industrial Revolution. Edited by Nancy W Gleason. Singapore: Palgrave Macmillan. 